IWONA BURKACKA

Uniwersytet Warszawski

Instytut Języka Polskiego

\title{
Klasyfikacja słowotwórcza nowszych zapożyczeń
}

Słowa klucze: status elementów obcych, motywacja, compositum, formantoid

Zapożyczanie wyrazów obcych nie jest tylko zjawiskiem wpływającym na charakter i zasoby współczesnej leksyki. Proces ten oddziaływał i oddziałuje na kształt polskiego systemu słowotwórczego. Wyrazy pochodzenia obcego stają się bowiem podstawami nowych słów, źródłem nowych formantów, a także nowych modeli słowotwórczych i szerzej - nowych sposobów derywacji. W ten sposób zmienia się nie tylko repertuar dostępnych morfemów, z których tworzy się słowa, ale i sposobów ich łączenia. Niektóre z nich zaczynają funkcjonować w kilku językach, co pozwala mówić o internacjonalizacji w słowotwórstwie, jak czyni to Krystyna Waszakowa (2005).

Znoszone zostają także ograniczenia strukturalno-semantyczne w łączliwości wielu sufiksów. Na przykład przyrostek -ow(y), łączący się początkowo z tematami rodzimych podstaw, z czasem zaczął występować z tematami wyrazów zapożyczonych ${ }^{1}$, „wkroczył - jak ujmuje to Krystyna Kleszczowa - na tereny, które pierwotnie obsługiwane były przez przyrostek -ny (adaptacja zapożyczeń, derywacja od rzeczowników abstrakcyjnych)" (Kleszczowa 2004: 59). W okresie po II wojnie światowej stał się niezwykle produk-

${ }^{1}$ Na ten temat pisała m.in. H. Satkiewicz (1969: 136), K. Kowalik (1977: 71) czy A. Grybosiowa (2003: 87). 
tywnym afiksem, charakteryzującym się niezwykłą łatwością w tworzeniu derywatów pochodnych od zapożyczeń, nawet tych słabo przyswojonych, np. big-beatowy, weekendowy, ensemblowy (Satkiewicz 1969: 136), co jest charakterystyczne także dla współczesnej polszczyzny, por. np. freestylowy, layoutowy. Funkcjonujące dziś ograniczenia łączliwości przyrostka -ow $(y)$ dotyczą tylko kilku grup: nazw osobowych, będących rzeczownikami pospolitymi, z sufiksami -acz, -arz, -owicz, rzeczowników zakończonych na -stw(o) (Kowalik 1977: 67, 70-71, Satkiewicz 1969: 129), nazw miejsc z sufiksami: -alni(a), -arni(a), -owni(a) ${ }^{2}$ oraz nazw zwierząt ${ }^{3}$ (Kallas 1998: 498). Warto jeszcze wspomnieć o wygłosie tematu podstawy, który może uniemożliwiać lub utrudniać przyłączenie omawianego przyrostka, np. elementy $/ c j(a)^{4}, / s j(a), / z j(a)^{5}$ czy - $(u m)^{6}$ występujące w zakończeniu wielu zapożyczeń.

Współcześnie w adaptacji morfologicznej wykorzystuje się niekiedy morfemy wcześniej niewystępujące w tej funkcji, np. sufiks -aśn(y), tworzący rodzime przymiotniki pochodne, typu grubaśny, długaśny, pojawił się w słowie stitaśny (a. sweetaśny, od ang. sweet), a także nieco mniej rozpowszechnionych bigaśny, kjutaśny (a. cute’aśny), pinkaśny, love’aśny. Wyrazami tymi posługują się w blogach młode dziewczęta, głównie uczennice gimnazjum. Formant -aśn(y) wprowadza nacechowanie ekspresywne do wymienionych rodzimych struktur odprzymiotnikowych. W przytoczonych neologizmach nastąpiło nawet wzmocnienie nacechowania uzyskane dzięki zestawieniu elementów niejednorodnych genetycznie i stylistycznie. Wspomniane przy-

2 Nie zawsze działa blokada łączliwości z formantami -arni(a) i -owni(a), por. szklarnia $\rightarrow$ szklarniowy, głosownia $\rightarrow$ głosowniowy, choć to tylko wyjątki.

3 Zwykle wskazuje się na to, że przymiotniki pochodne od tej grupy nazw są tworzone za pomocą derywacji paradygmatycznej. Jednak i to stwierdzenie należy doprecyzować. Rzeczywiście, w przymiotnikach derywowanych od nazw zwierząt dominują formy utworzone za pomocą zmiany paradygmatu, ale i w tej grupie leksemów znajdujemy liczne przymiotniki sufiksalne, np. koński, bobrowy, łosiowy, słoniowy, wydrowy. A w grupie rzeczowników będących nazwami ryb to właśnie sufiks - ow (y) najczęściej buduje przymiotniki (odwołuję się do danych zawartych w pracach licencjackich, które powstały pod moim kierunkiem w 2005 r.).

${ }^{4}$ W związku z tym, że w omawianych strukturach nie można mówić precyzyjnie o statusie morfologicznym wskazanych elementów, oddzielam je ukośnikiem.

5 Przymiotniki budowane są z udziałem przyrostka $-n(y)$.

6 Zwykle dołączany jest do nich sufiks - $\ln (n(y) \operatorname{lub}-n(y)$, choć możliwe jest połączenie z sufiksem -ow $(y)$, o czym wspomina H. Satkiewicz, podając przykład przymiotnika pochodnego od rzeczownika akwarium $\rightarrow$ akwariowy (Satkiewicz 1969: 136). 
miotniki są jednymi z wielu przykładów hybryd, których masowy przyrost i funkcjonowanie w wielu sferach słownictwa wpłynęły na zmianę ich oceny normatywnej.

Jednak słowotwórczy ogląd nowszych zapożyczeń nie tylko pozwala na wzbogacenie listy sufiksów i podstaw słowotwórczych lub uchwycenie zmian w łączliwości formantów, lecz także nasuwa wiele wątpliwości dotyczących ich klasyfikacji.

Po pierwsze, pojawiają się trudności z usytuowaniem nowych ${ }^{7}$ struktur złożonych oraz z nazwaniem techniki słowotwórczej, dzięki której powstały ${ }^{8}$.

Zapożyczone struktury typu Watergate, workaholic, sexshop, będące wzorem dla wielu formacji analogicznych, utrwaliły bowiem masowo wykorzystywany wzorzec tworzenia słów (należących do różnych odmian polszczyzny), nazywany niekiedy przez językoznawców słowotwórstwem bez słowotwórstwa czy słowotwórstwem analogicznym.

Należy zastanowić się więc nad miejscem nowych struktur wśród wyrazów motywowanych i tym, jak je nazwać. Możemy albo zastosować dotychczasową terminologię i zaliczyć nowe struktury do istniejących grup derywatów: wtedy uznajemy np. słowa infomat, e-szkoła, agrokadra za zrosty ${ }^{9}$, albo tworzyć nowe terminy i modyfikować klasyfikację compositów. Wtedy mamy do dyspozycji co najmniej kilka możliwości: złożenia bezafiksalne, struktury złożeniowe, złożeniowce, złożenio-zestawienia, quasi-złożenia, złożenia zdezintegrowane, pseudozłożenia, złożenia z członem zwiazanym ${ }^{10}$ - po przyjęciu, że są to złożenia, lub możemy opisywać, jak czyni to K. Waszakowa, słowa ekstrazasilanie, superoferta jako derywaty proste i wpisywać elementy ekstra-, super- ${ }^{11} \mathrm{~W}$ zbiór prefiksów (Waszakowa 2005: 54-55, 71-72). Do statusu tych elementów jeszcze wrócę.

${ }^{7}$ Choć owa nowość jest dość względna. Lecz nie czas powstania tych struktur jest przedmiotem opisu (datacją neologizmów, a zwłaszcza weryfikacją ustaleń, zajmują się J. Wawrzyńczyk i P. Wierzchoń), a ich charakterystyka słowotwórcza.

${ }^{8} \mathrm{Na}$ niejednolitość opisów zwraca uwagę Donata Ochmann w artykule pt. Między dezintegracja a analogia. O pewnym typie złożeń współczesnej polszczyzny (Ochmann 2002) i pracy Nowe wyrazy złożone o podstawie zdezintegrowanej w języku polskim (Ochmann 2004: 38-45).

9 Z wieloma zastrzeżeniami.

10 Bogatą listę propozycji terminologicznych podają K. Waszakowa (2005: 48-58) i D. Ochmann (2004: 38-45).

11 Elementy te nie są nowe, a niektóre derywaty wykorzystujące w jednej strukturze kilka z nich, np. ultraextrasuperheterodynamiczny, pochodzą według najnowszych 
Możemy traktować nowe struktury jako pewien podtyp zrostów (tak czyni H. Jadacka ${ }^{12}$ wobec złożeń bezafiksalnych z pierwszym członem w postaci skróconej, typu ekofundusz, teleserial - Jadacka 2001: 94, 106) lub wydzielać jako odrębną grupę compositów (wtedy podział struktur złożonych wyglądałby następująco: zrosty, złożenia właściwe - interfiksalne oraz (nowe) bezinterfiksalne, skrótowce, zestawienia (jeśli za Alicją Nagórko włączamy je do złożeń).

Można także dzielić nowe composita na podgrupy, wydzielane ze względu na opis członów. I tak, Krystyna Waszakowa odwołuje się do stopnia motywacji słowotwórczej i oddziela struktury o pełnej motywacji (ich podstawy słowotwórcze są samodzielnymi wyrazami, typu seksbiznes) od struktur o niepełnej motywacji, w których sytuuje złożenia z członem związanym (złożenia, w których motywowany jest tylko jeden z członów) i quasi-złożenia, czyli złożenia o dwóch członach związanych (niesamodzielnych) ${ }^{13}$. Do prefiksów zalicza te elementy, które nie mają statusu samodzielnego wyrazu, a ich znaczenie może być oddane lub przybliżone przez odpowiedni przyrostek rodzimy (np. post - po) lub przyimek (np. kontr - przeciw) ${ }^{14}$. Do tej grupy włącza także cząstki super- ${ }^{15}$, ekstra-, hiper-ze względu na to, że ich znaczenie intensywności bywa w innych wypadkach wyrażane przez morfemy słowotwórcze (Waszakowa 2005: 55). Stąd - jak sama badaczka zauważa - nieostra granica między derywacją prefiksalną a kompozycją.

Hanna Jadacka w swoim podziale wydziela w nowych strukturach złożenia bezinterfiksalne (np. seksoferta), prefiksoidalne (np. superwyczyn), prefiksoidalno-sufiksalne (np. multidyscyplinarny). Do pierwszych zalicza serie z powtarzającym się skróconym pierwszym składnikiem zrostu (np. ekorolnictwo) i złożeniowce (np. Amerbank).

ustaleń z okresu dwudziestolecia międzywojennego (wymieniony przykład z 1932 r.) (Wierzchoń 2008: 960).

12 Z tego ujęcia, zaproponowanego w 2001 roku, badaczka zrezygnowała w późniejszym tekście (Jadacka 2010: 331).

13 W myśl ustaleń R. Grzegorczykowej i J. Puzyniny (Grzegorczykowa, Puzynina 1998: 456, 464-468). Podobny podział nowych złożeń (tzn. uwzględniający stopień usamodzielnienia zdezintegrowanego członu i rodzaj drugiego członu złożenia) prezentuje D. Ochmann (2004: 52).

14 Za R. Grzegorczykową i J. Puzyniną (Grzegorczykowa, Puzynina 1998: 430-432, 468, 497).

15 Także jako prefiks opisuje ten element H. Jadacka we wcześniejszej pracy (Jadacka 1995: 1611). 
Przyjęcie oglądu ujmującego ucięcie jako istotny wyróżnik derywacji pozwala zaś Iwonie Kaproń-Charzyńskiej widzieć w obrębie interesujących nas struktur następujące typy derywatów: afiksoidalne (prefiksoidalne, np. bio/geneza, sufiksoidalne, np. trabant/gate) oraz interfiksalno-sufiksoidalne, np. epidemi-o/logia ${ }^{16}$, ujemno-interfiksalne, np. lustr<>-o-maniak (od lustracja), ujemno-interfiksalno-sufiksalne, np. angl<>-o-języcz-ny, ujemno-interfiksalno-sufiksoidalne, np. alerg<>-o/logia, ujemno-prefiksoidalne, np. izo/term $<>a$ (od izo- + termiczny) (Kaproń-Charzyńska 2005: 49).

Można wreszcie za Alicją Nagórko włączyć nowe struktury w obręb adaptacji, która w jej ujęciu jest jednym z rodzajów słowotwórstwa (obok derywacji właściwej i kompozycji - por. Nagórko 1998: 189-191), i nie roztrząsać, czy to derywaty proste czy złożenia.

Mamy więc do dyspozycji albo bardzo szczegółowe opisy, często sprzeczne w szczegółach (status cząstki super-, do której jeszcze powrócę) albo bardzo ogólne. Moim zdaniem, trudno nazywać zrostami nowe struktury, ponieważ mechanizm ich powstania znacznie się różni od typowych zrostów ${ }^{17}$, np. formacji dusigrosz czy Wielkanoc. Tworzenie nowych złożeń nie polega na zrastaniu się wyjściowych struktur składniowych w jedną całość, lecz na celowym i planowym łączeniu dwóch podstaw czy podstawy i formantoidu (zależnie od przyjętej terminologii i statusu owego obcego elementu), czemu często towarzyszy zmiana szyku i nierzadko ucięcie. Niekiedy ostatnia głoska pierwszego elementu złożenia pełni pozornie rolę interfiksu - łączy pierwszy człon z drugim (przeważnie o nagłosie spółgłoskowym, np. eko+ turystyka, wczasy, gospodarstwo). Zwykle wygłos pierwszego segmentu jest samogłoskowy $(o, a, e)$, rzadziej spółgłoskowy, co wizualnie zbliża omawiane struktury do złożeń interfiksalnych.

Od lat złożenia z członami obcymi tworzą terminologię, nawet lingwistyczną - metalingwistyka, pedolingwistyka, socjolingwistyka, etnolingwistyka, ekolingwistyka ${ }^{18}$, pragmalingwistyka, neurolingwistyka, interlingwi-

${ }^{16} \mathrm{~W}$ opisie na stronie 49 pojawił się błąd - nie zastosowano ukośnika dla zaznaczenia sufiksoidu.

17 Por. uwagi H. Jadackiej dotyczące zrostów (Jadacka 2010).

18 Termin ten wymienia m.in. Aleksander Kiklewicz i podaje, że jest to kierunek „badań nad językiem, którego przedmiotem jest funkcjonowanie języków etnicznych w synchronii i diachronii, kontakty (a także konflikty) językowe, polityka językowa (w szczególności planowanie językowe) itd.” (Kiklewicz 2008: 10). 
styka, iurislingwistyka (a. jurislingwistyka) i legilingwistyka ${ }^{19}$. Człon ten bywa też zubożany, jak w nazwie jednego z czasopism językoznawczych LingVaria. Jak zaklasyfikować wymienione przykłady? Niewątpliwie to złożenia, które na pewno nie są interfiksalne.

Ten sposób derywowania jest stosowany zarówno w obrębie nazw pospolitych, jak i własnych. Spotykamy tam klasyfikacje włączające przykłady omawianych struktur w obręb skrótowców. Badacze posługują się wtedy terminem złożeniowce (por. Jadacka 2001: 95) lub skrótowce złożeniowe (por. Podracki 1999: 18).

Po drugie, kłopot sprawia pograniczny status nowych elementów, np. $e$-, -ex ${ }^{20}$, -gate, eko-. Nawet stosowane w ich opisie terminy: prefiksoid ${ }^{21}$, sufiksoid, afiksoid, poloprefiks, premorfema, element, człon złożenia, obcojęzyczny komponent złożenia, nie wskazująjednoznacznie na typ derywatu powstałego z ich udziałem: prosty czy złożony (pierwsze terminy) lub typ złożenia. Próbują raczej wskazać na podobieństwa (terminy z cząstką -oid) czy miejsce w strukturze (premorfema). Sformułowania: element, człon, komponent złożenia, ujawniają przynależność derywatów z tymi elementami do compositów, jednak nie dookreślają ich statusu. Członami derywatów są przecież zarówno tematy słowotwórcze, jak i formanty (Grzegorczykowa, Puzynina 1998: 363), a terminu człon compositum używa się zwykle, gdy nie można zastosować terminu temat słowotwórczy (por. Grzegorczykowa, Puzynina 1998: 455) - człony zwiazane, jedno- lub dwustronnie. Terminy te są bardzo pojemne, a wobec kłopotów z klasyfikacją tych elementów - bardzo przydatne, zwłaszcza w dydaktyce.

Wyrażenie: obcojęzyczny komponent złożenia wskazuje na obcość elementu, która przecież z czasem jest mniej odczuwana i w związku z procesami asymilacji przestaje chyba być najważniejszym wyróżnikiem. Po pewnym czasie komponenty te zaczynają być dołączane do rodzimych tematów słowotwórczych, co świadczyć może o ich przyswajaniu. Na przykład cząstka-burger jest dołączana do rzeczowników soja, bekon, wieś i kurczak w na-

19 Utworzony od lingua legis. Wyraz ten występuje w nazwie jednostki organizacyjnej - Pracowni Legilingwistyki w Instytucie Językoznawstwa Uniwersytetu im. Adama Mickiewicza w Poznaniu i publikacjach z zakresu teorii przekładu prawniczego.

${ }^{20}$ Występujący w licznych wariantach: -ix, $-u x,-y x,-a x,-o x$.

${ }^{21}$ W znaczeniu przejętym przez K. Waszakową od językoznawców czeskich i stosowanym też przez H. Jadacką (inaczej R. Grzegorczykowa i J. Puzynina (1979: 24-25) - cząstki wydzielane w wyrazach podzielnych tylko formalnie). 
zwie kanapek: sojaburger, bekonburger, wieśburger, kurczakburger, a element $e$ - do słów szkoła, zakupy, podpis. Odczuwanie obcości stopniowo się zmniejsza, a tworzenie derywatów (obok odmiany i zmian w pisowni lub wymowie) jest uznawane za jeden ze sposobów przyswajania zapożyczeń. Niekiedy wyodrębnione elementy zaczynają żyć samodzielnie, np. człon bus (np. jechać busem, derywaty: busik, buspasy), van (jechać vanem, minivan), wspomniany wyżej burger ${ }^{22}$, net (odmienny).

Terminy: prefiksoid, sufiksoid (i afiksoid) wskazują zaś na podobieństwa do prefiksów i sufiksów. Zbieżności dotyczą kilku aspektów:

a) znaczna część nowych elementów występuje w stałych pozycjach ${ }^{23}$ : przed tematem (np. e-, tele-, eko-) lub po nim (-gate, -ax, -burger), podobnie jak prefiksy i sufiksy. Zauważmy jednak, że niektóre człony złożeń właściwych też występują w określonych pozycjach względem drugiego tematu, np. -jad, -żer[+ny], -wtos[+(y)] w pozycji po pierwszym segmencie (trawojad, trupojad, mrówkojad, paliwożerny, roślinożerny, mięsożerny, dtugowtosy, szorstkowtosy, ciemnowłosy).

b) łatwość dołączania do tematów, wiążąca się z brakiem alternacji. Choć niektóre złożenia interfiksalne też tworzą struktury, które mogą być dość łatwo uzupełniane nowymi elementami, pojawiającymi się w wyznaczonej pozycji (*gruszkojad, *śliwkożerny, *purpurowłosy), podobnie człony jasn-, ciemn-, złocist- (np. jasnozielony, ciemnozielony, złocistozielony).

c) podobna długość. $Z$ reguły nowe komponenty nie są zbyt rozbudowane, zwykle jednosylabowe lub dwusylabowe ${ }^{24}$. Wymienione człony złożeń interfiksalnych budujące długie szeregi compositów też zwykle nie są zbytnio rozbudowane (-jad, -żerny, -chłonny, -chron, jasn- itp.).

d) zbliżona aktywność derywatów. Jak wykazał Jarosław Łachnik w pracy Złożenia polskie - opis gniazdowy, „derywaty z dodanymi podstawami obcymi i ich kontynuanty wykazują aktywność zbliżoną do derywa-

${ }^{22}$ K. Waszakowa zwraca uwagę, że element burger funkcjonuje już jako samodzielny wyraz, przyswojony fleksyjnie, oraz podaje przykłady napisów na etykietach produktów i informacji podawanych w reklamach, np. burgery rybne panierowane (Waszakowa 2005: 82, przypis 61).

23 Zwraca na to uwagę I. Kaproń-Charzyńska (2005: 43) i wymienia jeszcze dwa podobieństwa: powtarzalność i bezpośrednie połączenie z podstawą słowotwórczą (człony nagłosowe).

${ }^{24} \mathrm{Na}$ dwusylabowość pierwszego członu zwraca uwagę D. Ochmann (2004: 52). 
tów prostych właściwych ${ }^{25}$ (obciążenie modeli, ich przedłużenie na dalsze takty derywacyjne)" (Łachnik 2009: 141).

Terminy prefiksoid i sufiksoid wprowadzają jednak strefę przejściową pomiędzy derywacją prostą a kompozycją, strefę, w której nowe struktury mogą być - w skrajnych przypadkach - tworzone bez tematów słowotwórczych, tylko z samych -oidów, np. hipotetyczna forma megagate.

Po trzecie, nowe elementy wpływają na sposoby wydzielania cząstek z zasobu rodzimego słownictwa i ich status. $W$ wielu nazwach własnych (i nie tylko) pojawiają się człony -bud-, -rol-, -gum- wydzielone z rodzimych przymiotników budowlany, rolny, gumowy, chętnie wykorzystywane w nazwach firm czy sklepów, jak można sądzić nie tylko z powodu ich skrótowości, ale i przejrzystości znaczeniowej (wzmacnianej niekiedy ortografią: zastosowaniem wielkiej litery). Ich wzorem mogły być funkcjonujące dłużej komponenty -med-, -dent-, o obustronnej łączliwości i międzynarodowym charakterze. Owe krótkie, ponieważ zwykle jednosylabowe, człony bywają również wydzielane z rzeczowników ${ }^{26}$ - art- (artykuty), -mat- (materiaty), -lab-(laboratorium) i doklejane podobnie jak zapożyczone człony.

Po czwarte, status niektórych elementów się zmienia, np. cząstka super pierwotnie traktowana jako niesamodzielny, zapożyczony człon złożeń z czasem się usamodzielniła, co pozwala derywaty typu superdziewczyna czy superubaw opisywać jako derywaty złożone, zbudowane z dwóch samodzielnych tematów słowotwórczych. Przecież element super funkcjonuje jako odrębne słowo i buduje derywaty proste: superowy, superowo, przesuper. Podobny proces obejmuje wyrazy ekstra, mini, maks i wymienione wcześniej burger, van, bus ${ }^{27}$, net, a zdaniem niektórych badaczy także cyber, porno, stereo (Ochman 2000: 23-34; 2002: 327 i 2004: 170-172) oraz eks ${ }^{28}$ i makro $^{29}$ (por. Kaproń-Charzyńska 2005: 44).

25 Derywaty ,utworzone tylko dzięki operacjom słowotwórczym wykonywanym na jednej podstawie słowotwórczej (bez udziału podstawy spoza gniazda)" (Łachnik 2009: 32).

${ }^{26}$ Niekiedy to jednosylabowe rzeczowniki, np. dom.

27 Zdaniem Iwony Kaproń-Charzyńskiej to niesamodzielna jednostka (człon zdezintegrowany) ze względu na związek formalny i semantyczny z leksemem autobus oraz łączenie się z tematem słowotwórczym za pomocą interfiksu, np. sklepobus (Kaproń-Charzyńska 2005: 45); podobnie K. Waszakowa (Waszakowa 2005: 59).

28 O znaczeniu 'były, była'.

29 Także mikro (I.B.), a może również info- ('informacja') i wieloznaczne euro- (por. Ochmann 2004: 118, 140-141). 
Dyskusyjny jest także status elementów eko- ${ }^{30}$, -wege. Zaczynają funkcjonować samodzielnie, np. żyj eko (czyli ekologicznie), sposoby na życie eko, zostań wege (wegetarianem lub weganem), kuchnia w rytmie wege, śmietanki wege. Skrócone wersje słów są charakterystyczne zwłaszcza dla gwar młodzieżowych, szkolnych i potocznej odmiany języka, z czasem wobec upotocznienia języka ${ }^{31}$ pojawiają się w leksyce ogólnej. Pytanie więc, czy mamy do czynienia z samodzielnymi jednostkami czy z członami odsyłającymi nas do pełniejszych wersji. Czy powinniśmy dziś mówić o ucięciu czy może już nie?

Po piąte, wieloetapowość procesu zapożyczania powoduje możliwą lub konieczną reinterpretację niektórych struktur (wyrazy niemotywowane staja się motywowane, czyli przejście od adaptacji do słowotwórstwa lub zmiana synchronicznego opisu derywatów, np. wspomnianych wyżej złożeń), oraz zmianę funkcji formantu - można mówić tu o nabywaniu nowych funkcji, np. -eria.

I tak, przejęte z innych języków słowa mogą po pewnym czasie być opisywane jako wyrazy motywowane czy motywowane jednostronnie. Możliwość reinterpretacji pojawia się, gdy przejmujemy do polszczyzny ich podstawy słowotwórcze czy wyrazy, które mogą być za nie uznane, a także słowa mające wspólne człony. Zapożyczyliśmy słowo internet (podzielne na gruncie języka angielskiego), który po pewnym czasie został skrócony do formy net, funkcjonującej jako samodzielny wyraz (i w języku angielskim, i polskim: zajrzeć do netu, znaleźć w necie), później pojawiło się w polszczyźnie słowo intranet, które bywa definiowane jako 'internet wewnętrzny (działający wewnątrz firmy czy instytucji)'. Wyraz intranet, podzielny na gruncie języka angielskiego, zaczyna być segmentowany również w polszczyźnie: następuje wydzielenie dwóch członów: intra ${ }^{32}$ i wspomnianego wcześniej słowa net, funkcjonującego w potocznej odmianie języka. I choć i internet, i intranet to złożenia utworzone na gruncie języka angielskiego ${ }^{33}$, to na gruncie polszczyzny - wobec usamodzielnienia się członu net, przyswojenia zapożyczenia internet i występowania wyrazów z elementem -net - pojawia się możliwość

30 O usamodzielnianiu się tego członu pisała D. Ochmann (2004: 63-64).

31 U podstaw leżą zmiany kulturowe.

32 Cząstka intra-, pochodząca z łaciny i niosąca znaczenie 'wewnątrz', występuje w derywacie intramolekularny.

33 Internet z cząstki net 'sieć' i elementu o międzynarodowym charakterze inter-, a intranet to połączenie cząstki intra- i internetu (por. Collins Essential English Dictionary 2end, Edition 2006). 
słowotwórczego podziału zapożyczonego intranetu, a może nawet i interne$t u$, tym bardziej że funkcjonuje też słowo ekstranet ${ }^{34}$ (też zapożyczone z jęz. angielskiego extranet).

Zapożyczanie nowych słów przynosi też konieczność zrewidowania poglądów dotyczących funkcji formantu. I tak funkcjonujący od XVIII wieku ${ }^{35}$ sufiks - eri $(a)^{36}$ budował derywaty należące do trzech grup znaczeniowych: nomina collectivi, nomina essendi i nomina actionis, których podstawami były rzeczowniki o znaczeniu konkretnym. Krystyna Długosz-Kurczabowa sądzi, że ,produktywność omawianego formantu związana była z epoką literacką cyganerii warszawskiej i cyganerii krakowskiej”, a „dziś można już mówić o regresie tego formantu" (Długosz-Kurczabowa 1986: 470). Krystyna Waszakowa wskazała 4 derywaty, których znaczenie nie mieści się w wymienionych wyżej grupach. Są to dwie nazwy miejsc: perfumeria i pizzeria oraz nazwa nosiciela cechy arkebuzeria (historyzm) i nazwa nieosobowego subiektu czynności: sceneria 'to, co otacza scenę' (Waszakowa 1994: 98). Jej zdaniem sufiks -eri(a) jest formantem produktywnym, choć niezbyt często tworzącym nowe derywaty (Waszakowa 1994: 97-99). Tymczasem ostatnie lata przynoszą wiele nazw miejsc z omawianym sufiksem: bileteria $^{37}$, kebaberia, kafeteria, pierogeria, które się przyjęły w polszczyźnie oraz okazjonalizmy lub nazwy własne (np. CZAT-eria).

Doszło więc do swoistej ewolucji formantu - realizuje on nowe funkcje wcześniej nieobecne w polszczyźnie, a występujące w systemach innych języków. Sufiks -eri(a) tworzy współcześnie nazwy lokali gastronomicznych. Nowa funkcja sufiksu - podobnie jak nowe znaczenia wielu wyrazów - zaczyna dominować nad starymi funkcjami: liczniej tworzone są derywaty, które wykorzystują nową funkcję formantu (podobnie jak nowsze znaczenia słów: promocja, promować, pasja, ikona są szybciej przywoływane niż starsze i często podawane jako pierwsze). Widać więc pewne podobieństwa do procesu neosemantyzacji.

Zapożyczone wyrazy, dostarczające wzorów tworzenia słów, nie tylko więc wzbogacają repertuar środków - morfemów, z których tworzymy neo-

34 Połączenie dwóch lub większej liczby intranetów.

35 Według K. Długosz-Kurczabowej (Długosz-Kurczabowa 1986).

${ }^{36}$ Nowe derywaty z sufiksem -eri(a) opisuję w artykule $O$ sufiksach -nia $i$-eria w funkcji wykładników nazw miejsc (Burkacka 2010).

37 Wymieniony przez K. Waszakową w późniejszej pracy (Waszakowa 2005: 67, 121). 
logizmy, i sposobów ich łączenia, ale i przebudowują nasz sposób widzenia złożeń, nie wspominając o ich ocenie normatywnej, która uległa znacznemu złagodzeniu.

\section{Bibliografia}

BurkaCKa I., 2010, O sufiksach -nia i -eria w funkcji wykładników nazw miejsc, LingVaria, nr 1 (9), s. 31-38.

DŁugosz-Kurczabowa K., 1986, Formant -eria w języku polskim, Poradnik Języko$w y$, z. 7, s. 466-470.

Grybosiowa A., 2003, Język wtopiony w rzeczywistość, Katowice: Wydawnictwo Uniwersytetu Śląskiego.

Grzegorczykowa R., Puzynina J., 1979, Stowotwórstwo wspótczesnego języka polskiego, Warszawa: Państwowe Wydawnictwo Naukowe.

Grzegorczykowa R., Puzynina J., 1998, Problemy ogólne słowotwórstwa, w: R. Grzegorczykowa, R. Laskowski, H. Wróbel (red.), Gramatyka współczesnego języka polskiego, t. 2: Morfologia, wyd. drugie, Warszawa: Wydawnictwo Naukowe PWN, s. 361-388.

JADaCKa H., 1995, Cząstki słowotwórcze, w: A. Markowski (red.), Nowy stownik poprawnej polszczyzny PWN, Warszawa: Wydawnictwo Naukowe PWN.

JADACKA H., 2001, System slowotwórczy polszczyzny (1945-2000), Warszawa: Wydawnictwo Naukowe PWN.

JADACKA H., 2010, Zrosty - najmniej znana struktura słowotwórcza, w: K. Waszakowa, T. Korpysz, J. Chojak (red. nauk.), Człowiek - słowo - świat, Warszawa: Wydawnictwa Uniwersytetu Warszawskiego, s. 325-332.

Kallas K., 1998, Przymiotnik, w: R. Grzegorczykowa, R. Laskowski, H. Wróbel (red.), Gramatyka wspótczesnego języka polskiego, t. 2: Morfologia, wyd. drugie, Warszawa: Wydawnictwo Naukowe PWN, s. 469-523.

KaProń-CharzyŃSKa I., 2005, Derywacja ujemna we wspótczesnym języku polskim. Rzeczowniki i przymiotniki, Toruń: Wydawnictwo TOP KURIER.

KikLewicz A., 2008, Dwanaście funkcji języka, LingVaria, nr 2(6), s. 9-27.

Kleszczowa K., 2004, Przypadek i prawidłowość w przemianach systemu słowotwórczego, Poradnik Językowy, z. 2, s. 51-65.

KowaLik K., 1977, Budowa morfologiczna przymiotników polskich, Wrocław: Wydawnictwo Polskiej Akademii Nauk.

ŁACHNIK J., 2009, Złożenia polskie - opis gniazdowy, maszynopis pracy doktorskiej, Warszawa. 
NAGÓRKo A., 1998, Zarys gramatyki polskiej, wyd. III, Warszawa: Wydawnictwo Naukowe PWN.

Ochmann D., 2000, Złożenia z cyber-we współczesnym języku polskim, Język Polski $L X X X$, z. 1-2, s. 23-34.

Ochmann D., 2002, Między dezintegracją a analogią. O pewnym typie złożeń współczesnej polszczyzny, Język Polski LXXXII, z. 5, s. 322-329.

Ochmann D., 2004, Nowe wyrazy złożone o podstawie zdezintegrowanej w języku polskim, Kraków: Księgarnia Akademicka.

PoDracki J., 1999, Wstęp, w tegoż: Stownik skrótów i skrótowców, Warszawa: Wydawnictwo Naukowe PWN.

SATKIEwicz H., 1969, Produktywne typy stowotwórcze wspótczesnego języka ogólnopolskiego, Warszawa: Wydawnictwa Uniwersytetu Warszawskiego.

WaSzaKowa K., 1994, Stowotwórstwo wspótczesnego języka polskiego. Rzeczowniki sufiksalne obce, Warszawa: Wydawnictwa Uniwersytetu Warszawskiego.

Waszakowa K., 2005, Przejawy internacjonalizacji w stowotwórstwie wspótczesnej polszczyzny, Warszawa: Wydawnictwa Uniwersytetu Warszawskiego.

WierzchoŃ P., 2008, Jaskótki przejawów internacjonalizacji w stowotwórstwie wspótczesnej polszczyzny z lat 1894-1984. Tylko sto przykładów, Pruszków k. Łasku: Oficyna Wydawnicza Leksem Anna Bralewska.

\section{Word-formation classification of more recent borrowings}

(s u m mary)

The process of borrowing foreign words influences the form of Polish word-formation (it enriches the list of possible formants and word roots, and disseminates new ways of derivation), it contributes to lifting the restrictions imposed on the collocation of suffixes or morphemes which serve to adapt foreign words, furthermore, it influences the change of normative assessment of several forms.

In the synchronic description, the word-formation classification of structures containing genetically foreign elements, such as infomat, e-szkoła, agrokadra, causes several problems because of the multiplicity of terminological propositions, the status of the discussed elements, and the fact that the process of gaining autonomy has many stages. The latter may cause a reinterpretation of certain structures (words which are non-motivated become motivated, which sometimes makes it necessary to change the description of the functions of the morpheme). New compounds also influence the productivity of native word-formation processes. 